\title{
Zastosowanie gier symulacyjnych w kształceniu w zakresie współczesnych koncepcji zarządzania*
}

\section{Streszczenie}

W opracowaniu zostały przedstawione wyniki badania dotyczącego efektów stosowania gier symulacyjnych w ramach prowadzenia zajęć z przedmiotu współczesne koncepcje zarządzania. Zastosowaną metodą, oprócz studiów literatury przedmiotu, było badanie ankietowe przeprowadzone na próbie 142 studentów drugiego stopnia studiów stacjonarnych w latach akademickich 2014/2015 i 2015/2016. Przedstawiono podstawowe kwestie związane z wykorzystaniem gier symulacyjnych w procesie dydaktycznym i krótko scharakteryzowano dwie gry wykorzystane w badaniu. Następnie zaprezentowano i zinterpretowano najważniejsze wyniki badania ankietowego. Sformułowano także zalecenia odnośnie do wykorzystywania gier symulacyjnych w procesie nauczania na poziomie akademickim.

Słowa kluczowe: metody dydaktyczne, gry symulacyjne, efekty nauczania, współczesne metody zarządzania.

Klasyfikacja JEL: A2, D2, I23, L23, M11.

Maciej Walczak, Uniwersytet Ekonomiczny w Krakowie, Wydział Zarządzania, Katedra Metod Organizacji i Zarządzania, ul. Rakowicka 27, 31-510 Kraków, e-mail: walczakm@uek.krakow.pl

* Artykuł powstał w wyniku realizacji tematu badawczego finansowanego ze środków przyznanych Wydziałowi Zarządzania Uniwersytetu Ekonomicznego w Krakowie w ramach dotacji na utrzymanie potencjału badawczego. 


\section{Wprowadzenie}

Pracownik dydaktyczny prowadzący zajęcia z młodzieżą w ramach ćwiczeń na wyższej uczelni ma do dyspozycji wiele metod dydaktycznych. W doborze konkretnej metody powinno się uwzględniać różne kwestie, takie jak np.: realizowany temat, możliwości techniczne (m.in. wyposażenie, rodzaj sali), predyspozycje prowadzącego czy liczebność grupy ćwiczeniowej. Należy również mieć na uwadze zróżnicowanie przebiegu zajęć, aby uniknąć monotonii prowadzącej do znużenia studentów biorących w nich udział. Wykorzystywany na Uniwersytecie Ekonomicznym w Krakowie system informatyczny, który spełnia formalne wymogi Krajowych ram kwalifikacji przy przygotowywaniu kart przedmiotów, umożliwia wybranie takich metod dydaktycznych, jak: wykład audytoryjny, konwersatorium, prezentacja, dyskusja, praca w grupach, symulacja, analiza przypadku, inscenizacja (odgrywanie ról), ćwiczenia tablicowe, ćwiczenia terenowe, e-learning, praca z podręcznikiem i ćwiczenia laboratoryjne (krk.uek.krakow.pl, data dostępu: 28.09.2016).

Jednym z kryteriów podziału metod dydaktycznych jest aktywność osób uczących się podczas zajęć. Pod tym względem wyróżniane są metody podające i aktywizujące. W grupie metod podających znajdują się takie, w wypadku których źródłem informacji i zarazem osobą aktywną jest prowadzący zajęcia. Tego typu metodami są np. wykład informacyjny czy instruktaż. Metody aktywizujące to natomiast takie, w których jest zakładany aktywny udział osób uczących się. Do metod aktywizujących zaliczane są m.in.: wykład problemowy, metoda sytuacyjna, inscenizacja [Harzyńska 2012, s. 202].

Celem opracowania jest zaprezentowanie możliwości wykorzystania gier symulacyjnych w kształceniu w zakresie współczesnych koncepcji zarządzania na wyższej uczelni. Przedstawione zostaną również wyniki badań ankietowych dotyczących postrzegania przez studentów dwóch gier symulacyjnych wykorzystywanych w ramach prowadzonych zajęć. Pierwsza z wspomnianych gier służy do obrazowania istoty lean manufacturing (,odchudzonej produkcji”) i just in time. Druga ukazuje zastosowanie reengineeringu w odniesieniu do procesu realizacji zamówienia klienta. Artykuł został opracowany na podstawie studiów literatury przedmiotu, doświadczeń autora w prowadzeniu zajęć ze wspomnianego przedmiotu, jak również badań ankietowych przeprowadzonych na zakończenie semestrów letnich w latach akademickich 2014/2015 i 2015/2016. 


\section{Rodzaje i struktura gier wykorzystywanych w procesie nauczania}

W formie narzędzia edukacyjnego gry stosowano już w XVIII w. w procesie szkolenia wojska. W XIX w. gry wojenne stały się obowiązkowym elementem kształcenia kadr w armii pruskiej. Na potrzeby cywilne zaczęto je wykorzystywać w XX w. - jako narzędzie w szkoleniach zawodowych i w dziedzinie rozwoju kadr w przedsiębiorstwach [Gruszczyńska 2014, s. 238].

Podział gier na gry edukacyjne i rozrywkowe (serious games $i$ entertaining games) zaproponował C.C. Abt w 1970 r. Celem gier edukacyjnych jest stymulacja procesu nabywania nowej wiedzy oraz kształtowanie określonych umiejętności. Gry rozrywkowe mają przede wszystkim bawić, zapewnić miłe spędzenie czasu. Zawsze jednak w grach rozrywkowych występują pewne elementy edukacyjne, chociażby utrwalanie prostych wzorców zachowań. W grach edukacyjnych powinny z kolei występować elementy zabawy, ponieważ sprzyja to osiąganiu efektów dydaktycznych [Wawrzeńczyk-Kulik 2013, s. 306]. Istotne w grach symulacyjnych jest współzawodnictwo uczestników [Ragin-Skorecka i Włodarczak 2011, s. 9].

Gry symulacyjne są klasyfikowane według różnych kryteriów. Podział może być dokonywany ze względu na [Ragin-Skorecka i Włodarczak 2011, s. 13-14]:

- liczbę uczestników (jednoosobowe, zespołowe),

- liczbę szczebli zarządzania objętych symulacją (jednoszczeblowe, dwuszczeblowe, wieloszczeblowe),

- liczbę stron zaangażowanych w rozwijanie problemu (jednostronne, dwustronne, wielostronne),

- liczbę etapów lub faz gry (jednoetapowe, dwuetapowe, wieloetapowe),

- wymóg współdziałania (konkurencyjne, kooperacyjne, mieszane lub niewymagające współdziałania).

W ramach gry może być symulowane działanie całego przedsiębiorstwa lub jego wybranych obszarów funkcjonowania (działów czy procesów), scenariusz może się zaś odnosić do konkretnej branży lub generalnie zarządzania w biznesie. Zgodnie z M. Wawrzeńczyk-Kulik [2013, s. 306], gdy gra odnosi się do procesów zarządzania lub procesów ekonomicznych, powinno się nazywać ją ekonomiczną grą symulacyjną lub grą symulacyjną biznesu.

Opisywane gry symulacyjne stanowią model określonego obszaru funkcjonowania przedsiębiorstwa, umożliwiają odzwierciedlenie warunków i zdarzeń, jakie mogą wystąpić w rzeczywistości. Model taki powinien obejmować [Wawrzeńczyk-Kulik 2013, s. 307]:

- role przypisane uczestnikom,

- scenariusz gry, 
- zasady określające dozwolone zachowania uczestników (możliwe jest również uwzględnienie wskazówek dotyczących ich pożądanych zachowań),

- mechanizmy reagowania na działania uczestników podejmowane podczas gry. Elementy te zostały zaimplementowane w obu analizowanych grach. W wypadku Stoczni rywalizujące zespoły porównują swoje wyniki punktowe. W Fabryce Notesów natomiast, w której wszyscy uczestnicy należą do jednego zespołu, reakcję na działania uczestników stanowi ocena efektywności procesu produkcyjnego dokonywana przez prowadzącego zajęcia.

\section{Wybrane badania dotyczące stosowania gier symulacyjnych}

Wartość edukacyjna gier symulacyjnych w procesie dydaktycznym była przedmiotem badań ze względu na osiągane dzięki wykorzystaniu tej metody efekty dydaktyczne, podniesienie atrakcyjności zajęć oraz poziomu zaangażowania uczestników. Badania nad efektywnością zastosowania gier symulacyjnych, ich wpływem na rozwój umiejętności i zdolności decyzyjnych zostały przeprowadzone m.in. przez jedną z australijskich szkół biznesu [Seethamraju 2011]. Analizą objęto kurs na temat procesów biznesowych wspomagany systemem klasy ERP. $\mathrm{W}$ celu zebrania danych posłużono się kwestionariuszem wypełnianym przed rozpoczęciem kursu i po jego zakończeniu. Zgromadzony materiał empiryczny pozwolił stwierdzić, że wyniki w zakresie poszerzenia zakresu wiedzy osiągane przez uczestników zajęć, na których wykorzystano grę, były lepsze niż w grupach z kursów biznesowych, na których jej nie zastosowano. Uczestnicy gry wypowiadali się ponadto bardzo pozytywnie na temat nowej metody przekazywania wiedzy.

W literaturze przedmiotu niektórzy autorzy analizują stosowanie gier symulacyjnych w różnych rodzajach modeli nauczania. Badania mające na celu empiryczne potwierdzenie skuteczności modeli cykli uczenia się w grach symulacyjnych biznesu zostały przeprowadzone na jednym z państwowych uniwersytetów w południowej części Tajwanu [Tao, Yeh i Hung 2015]. Zastosowanym narzędziem badawczym była dwuczęściowa ankieta, w której określano m.in. doświadczenie uczestnika w grach symulacyjnych zdobyte na wcześniejszych etapach edukacji oraz poziom umiejętności nabytych w trakcie zajęć. Uzyskane wyniki pozwoliły potwierdzić zasadność rozpatrywanych modeli cykli uczenia się oraz wskazać ograniczenia ich stosowania.

$\mathrm{Na}$ Uniwersytecie Elon w Stanach Zjednoczonych były prowadzone badania, w których porównywano wyniki w nauce i poziom zaangażowania na zajęciach studentów kursu psychologii edukacyjnej: grup uczestniczących w grach symulacyjnych oraz grup, w wypadku których nie stosowano gier symulacyjnych. Narzędziem badawczym wykorzystanym w analizie różnic wyników w nauce były testy 
przeprowadzone na początku i końcu kursu. Do pomiaru zaangażowania wykorzystano ankietę. W rezultacie, o ile w zakresie osiąganych wyników w nauce nie stwierdzono istotnych różnic, o tyle w grupie, w której program nauczania uwzględniał gry, zauważono wiele pozytywnych efektów. Były to m.in.: większe zaangażowanie w przebieg zajęć i pracę zespołową, rozwój umiejętności interpersonalnych, empatii oraz wypowiadania się na forum [Auman 2011, s. 159].

W Polsce zastosowaniem gier symulacyjnych i ich wpływem na angażowanie się uczestników w przebieg zajęć zainteresowała się J. Harzyńska. W roku akademickim 2010/2011 autorka ta przeprowadziła wśród studentów Wyższej Szkoły Humanistycznej Towarzystwa Wiedzy Powszechnej w Szczecinie badanie ankietowe, którego celem było określenie preferowanych przez nich metod dydaktycznych. Przeważająca większość respondentów preferowała zajęcia prowadzone metodami aktywnymi (95\% uczestników I stopnia studiów, 87,5\% II stopnia i 94,5\% ze studiów podyplomowych) [Harzyńska 2012, s. 205]. Analizowane w niniejszym opracowaniu gry symulacyjne należą właśnie do grupy metod aktywizujących.

\section{Charakterystyka gry Stocznia i Fabryka Notesów}

\subsection{Uwagi ogólne}

W ramach ćwiczeń z przedmiotu współczesne koncepcje zarządzania prowadzonych przez pracowników Katedry Metod Organizacji i Zarządzania Uniwersytetu Ekonomicznego w Krakowie realizowane są dwie gry symulacyjne. Gra Stocznia, prowadzona podczas zajęć z zakresu lean management, ma na celu przedstawienie możliwości eliminowania strat w procesach. Fabryka Notesów umożliwia natomiast ukazanie praktycznych zasad przebudowy procesów, które obowiązują w reengineeringu. Obie gry odnoszą się zatem do ugruntowanych teorii z zakresu nauki o zarządzaniu. W przeciwieństwie do większości opisywanych w literaturze współczesnych gier symulacyjnych żadna z nich nie wymaga wsparcia informatycznego. Takie wsparcie wykorzystywane jest np.: w LoGame - logistycznej grze decyzyjnej, opracowanej w ramach pracy magisterskiej w Katedrze Informatyki Wydziału Elektrotechniki, Automatyki, Informatyki i Elektroniki Akademii Górniczo-Hutniczej [Mieszaniec i Olejarz-Mieszaniec 2016, s. 62], w której koordynuje się dostawy i dystrybucję wyrobów w zakładzie produkcyjnym, w Park Manager - grze decyzyjno-fabularnej, w której uczestnicy wcielają się w zarządzających parkiem narodowym [Bernaciak i Brańka 2015], a także w różnych odmianach Gry piwnej (Beer Distribution Game lub Beer Game; pierwotnie Gra piwna była grą planszową) [Kołodziejczyk i Szołtysek 2012]. Wiele wskazuje na to, że liczba gier symulacyjnych z wykorzystaniem 
wsparcia informatycznego będzie wzrastać, np. w 2013 r. został ogłoszony przez Uniwersytet Marii Curie-Skłodowskiej w Lublinie przetarg skierowany do przedsiębiorstw informatycznych na opracowanie trzech gier symulacyjnych o tematyce logistycznej (http://www.umcs.pl/pl/przetargi-nieograniczone,926,opracowanie-i-wdrozenie-3-gier-symulacyjnych-majacych-sluzyc-jako-narzedzie-dydaktyczne-na-potrzeby-uruchomienia-prorynkowych-studiow-podyplomowych-zarzadzanie-procesami-logistycznymi,4542.chtm, data dostępu: 15.04.2017).

Do przeprowadzenia omawianych w opracowaniu gier wystarczy kilka prostych rekwizytów, opisy zasad i przebiegu rozdawane uczestnikom oraz objaśnienia prowadzącego ćwiczenia. Każda z wymienionych gier, włącznie z wprowadzeniem i omówieniem końcowym, trwa ok. 1,5 godz., można je zatem przeprowadzić w ciągu dwóch standardowych jednostek lekcyjnych, czyli w czasie jednego spotkania w ramach ćwiczeń.

\subsection{Stocznia}

Inspiracją do opracowania gry Stocznia były warsztaty przeprowadzone przez zespół trenerów podczas konferencji w Zakopanem w 2006 r., w trakcie których została wykorzystana Cup Game. Zadanie polegało na przygotowaniu zestawu plastikowych kubków do drinków, najpierw z zastosowaniem partii produkcyjnych, a następnie przepływu ciągłego z elementami systemu kanban.

W grze Stocznia grupa ćwiczeniowa jest dzielona na zespoły po 8-12 osób, rywalizują więc z sobą 2-3 zespoły. Każdy z nich otrzymuje kilkanaście kartek formatu A4, dwa pisaki różnych kolorów, parę nożyczek, krótki opis zasad gry oraz arkusz ocen. Gra składa się z czterech faz. W pierwszej zadaniem zespołu jest przygotowanie produkcji papierowych statków w dwóch rozmiarach: dużym i małym, zgodnie ze wzorem przedstawionym przez prowadzącego. Druga faza obejmuje produkcję ośmiu statków w podanej przez prowadzącego strukturze asortymentowej. Czas realizacji zamówienia wynosi tylko dwie minuty. Po tym etapie następuje ocena uzyskanych wyników, przeprowadzana na podstawie arkusza ocen, w którym kryteria zostały dobrane pod kątem identyfikacji i pomiaru strat ${ }^{1}$ występujących w realizowanym procesie. Za każdy przejaw marnotrawstwa zespół otrzymuje punkty, celem gry jest zatem zebranie jak najmniejszej liczby punktów. Zastosowanie arkusza obiektywizuje ocenę wykonania drugiej i czwartej fazy przez poszczególne zespoły. Trzecia faza polega na analizie wyników uzyskanych w fazie drugiej i wypracowaniu w zespołach lepszych rozwiązań dotyczących realizacji kolejnego zamówienia, czyli umożliwiających zebranie mniejszej liczby punktów. W czwartej fazie ponownie realizuje się zamówienie (na osiem statków,

\footnotetext{
${ }^{1}$ Innymi określeniami strat w terminologii lean są marnotrawstwo lub muda.
} 
w ciągu dwóch minut) i powtórnie oblicza wynik punktowy dla każdego zespołu. Zwycięża zespół, który uzyska najmniejszą liczbę punktów w czwartej fazie. Zazwyczaj wyniki zespołów podczas pierwszej realizacji zamówienia oscylują między 50 a 100 punktami, po wprowadzeniu usprawnień wynoszą natomiast ok. 20 punktów².

Po zakończeniu gry prowadzący ćwiczenia omawia na forum grupy rezultaty poszczególnych zespołów i przedstawia rozwiązanie wzorcowe, oparte na koncepcji lean i systemie kanban, pozwalające uzyskać wynik na poziomie 12 punktów.

\subsection{Fabryka Notesów}

Fabryka Notesów jest symulacją procesu z elementami gry, w której uczestniczy cała grupa ćwiczeniowa. W ramach wstępu prowadzący ćwiczenia rozdaje opis gry i dzieli grupę na działy fikcyjnego zakładu produkującego notesy ${ }^{3}$. W ten sposób zostają wydzielone działy: przygotowania materiału, cięcia, zszywania, kontroli jakości, sprzedaży i transportu wewnętrznego oraz magazyn. Prowadzący stara się, aby każda obecna na sali osoba została zaangażowana do pracy w którejś z komórek zakładu. Wyznacza również dwoje swoich asystentów, którzy będą zajmować się mierzeniem czasu i wykonywaniem innych prac organizacyjnych związanych z przebiegiem symulacji. Do magazynu zostają przekazane materiały niezbędne do wytwarzania notesów, a działy przygotowania, cięcia, zszywania i kontroli jakości otrzymują narzędzia, czyli nożyczki, linijki i zszywacz.

Kiedy wszyscy uczestnicy gry znają już swoje role, prowadzący prosi o wykonanie jednego papierowego notesu w celu przećwiczenia przez poszczególne działy realizacji określonych fragmentów procesu produkcyjnego. Po tak przeprowadzonej próbie następuje pierwsza faza produkcyjna, polegająca na dostarczeniu klientowi partii gotowych notesów. Faza ta trwa pięć minut. Po jej zakończeniu prowadzący ćwiczenia podsumowuje efekt pracy grupy, zapisując na tablicy następujące wskaźniki i mierniki: liczbę wyprodukowanych notesów, zaangażowanych osób, zużytych kartek i wadliwych notesów powstałych w procesie, a także wydajność przypadającą na jednego zatrudnionego w przedsiębiorstwie oraz zużycie kartek przypadające na jeden wyprodukowany notes. Biorąc pod uwagę zaangażowane zasoby, rezultaty pierwszej fazy są zazwyczaj niesatysfakcjonu-

${ }^{2}$ Oczywiście poprawa nie jest osiągana za każdym razem. Podczas prowadzenia gry przez autora zdarzały się zarówno zespoły osiągające podczas pierwszej realizacji zamówienia wynik 20 punktów, jak i takie, których wynik za drugim razem był znacznie gorszy od uzyskanego podczas realizacji pierwszego zamówienia.

${ }^{3} \mathrm{~W}$ wypadku licznej grupy ćwiczeniowej istnieje możliwość utworzenia dwóch niezależnych i konkurujących z sobą zakładów produkcyjnych. 
jące, co przyznają sami pracownicy fabryki, dlatego też prowadzący zaleca grupie opracowanie zmian $\mathrm{w}$ procesie realizacji zamówienia $\mathrm{z}$ wykorzystaniem zasad reengineeringu. Uczestnicy zajęć wypracowują i wdrażają wspólne rozwiązanie. Gdy grupa jest gotowa, następuje ponowna realizacja procesu. Po zakończeniu drugiej fazy produkcyjnej prowadzący określa wyniki i na ich podstawie ocenia, czy reengineering procesu zakończył się sukcesem, czy też się nie powiódł.

Podsumowanie gry stanowi dyskusja nad zasadami metody reengineeringu, wskazanie, w jakim stopniu zasady te były respektowane podczas pracy zespołu, oraz prezentacja przez prowadzącego wybranych rozwiązań poszczególnych problemów występujących w analizowanym procesie, jakie zostały zastosowane przez studentów wykonujących to ćwiczenie w przeszłości.

\section{Wyniki badań}

Narzędziem oceny przez studentów zasadności zastosowania gier w nauczaniu współczesnych koncepcji zarządzania była ankieta, którą wypełniło 142 uczestników ćwiczeń prowadzonych przez autora w semestrze letnim w latach akademickich 2014/2015 i 2015/2016. Ankietę przeprowadzano każdorazowo na ostatnich zajęciach, po zakończeniu pisania przez studentów kolokwium. Badaniem zostali objęci studenci studiów stacjonarnych kierunku zarządzanie (pięć grup ćwiczeniowych) oraz rachunkowość i controlling (jedna grupa ćwiczeniowa).

Tabela 1. Tematy zrealizowane na ćwiczeniach i wykorzystane metody dydaktyczne

\begin{tabular}{|c|c|}
\hline Nazwa ćwiczenia & Metoda dydaktyczna \\
\hline Benchmarking & Studium przypadku \\
\hline $\begin{array}{l}\text { Wprowadzenie do lean manage- } \\
\text { ment }\end{array}$ & Ćwiczenie indywidualne, studium przypadku \\
\hline Kaizen & Rozwiązywanie problemu (praca zespołowa) \\
\hline Just in time i kanban & Gra Stocznia \\
\hline SMED & $\begin{array}{l}\text { Analiza materiału filmowego, rozwiązywanie problemu } \\
\text { (praca zespołowa) }\end{array}$ \\
\hline TPM & Ćwiczenie indywidualne \\
\hline 7 nowych metod TQM & Rozwiązywanie złożonego problem (praca zespołowa) \\
\hline Reengineering & Studium przypadku \\
\hline Reengineering & Gra Fabryka Notesów \\
\hline Outsourcing & Rozwiązywanie zadania (praca zespołowa) \\
\hline Balanced scorecard & Projekt zrównoważonej karty wyników (praca zespołowa) \\
\hline
\end{tabular}

Źródło: opracowanie własne. 
Pierwszą analizowaną kwestią był stopień zapamiętania przebiegu zajęć. W tym celu poproszono studentów o ocenę tego, jak pamiętają przebieg poszczególnych ćwiczeń z przedmiotu. Tematy zrealizowane w ramach ćwiczeń zostały wyszczególnione w tabeli 1. Należy jednak zaznaczyć, że temat dotyczący zrównoważonej karty wyników nie był realizowany na zajęciach, studenci mieli go opracować samodzielnie, odpowiedzi dotyczące tego tematu należy zatem potraktować jako test wiarygodności respondentów. Uzyskane wyniki zostały zaprezentowane na rys. 1.

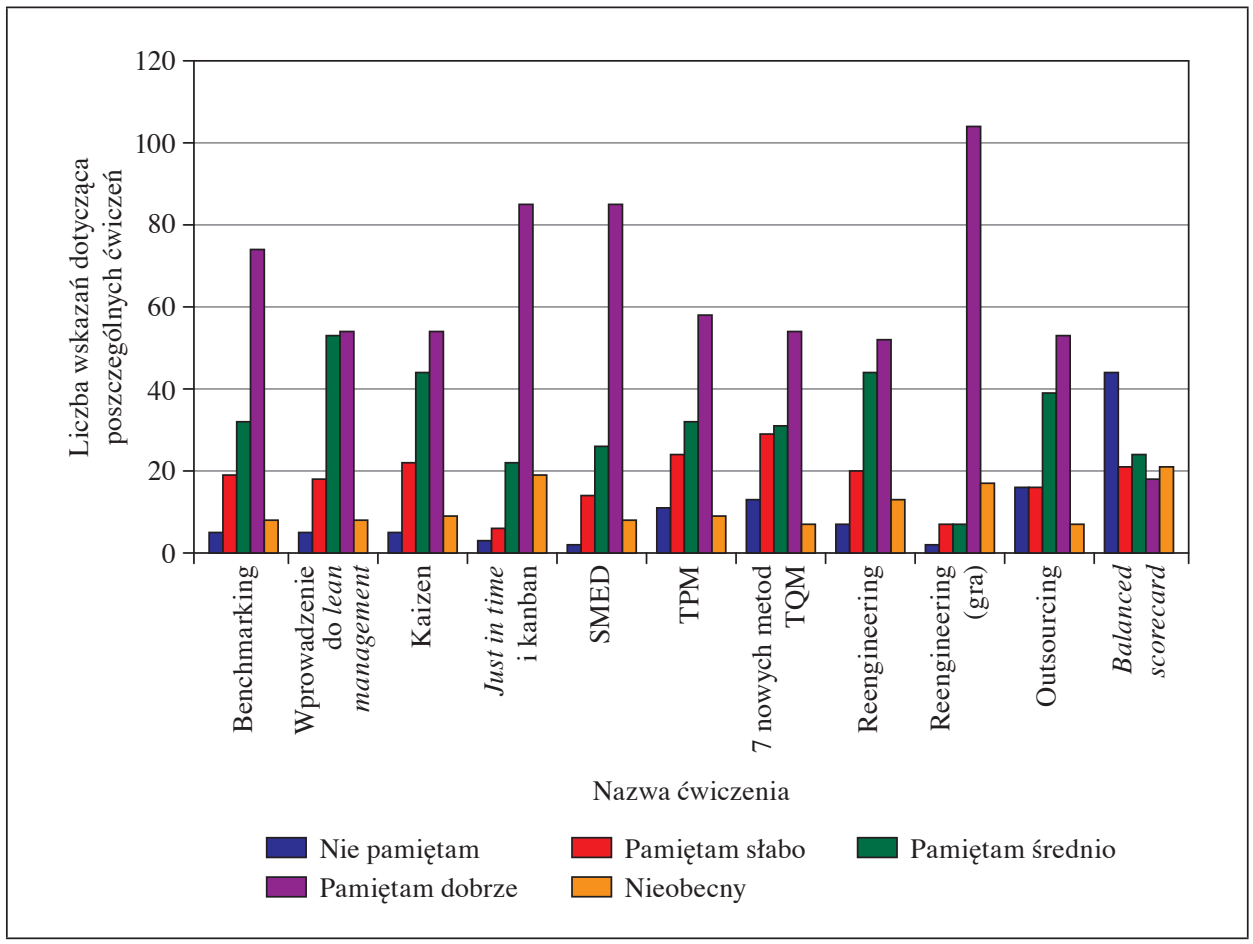

Rys. 1. Stopień zapamiętania przez studentów przebiegu poszczególnych zajęć Źródło: opracowanie własne.

Gry zespołowe zostały przeprowadzone na zajęciach dotyczących just in time (kanban) i reengineeringu. W wypadku tego drugiego tematu stopień zapamiętania, mierzony liczbą odpowiedzi „pamiętam dobrze”, był bardzo wysoki. Jeśli chodzi o ćwiczenia dotyczące just in time, studenci wskazali niższy stopień zapamiętania treści, liczba nieobecności była zbliżona. Podobnie wypadły zajęcia poświęcone metodzie SMED, na których analizowany był materiał filmowy. Na trzecim miejscu znalazły się zajęcia z benchmarkingu, na których przeprowadzono studium 
przypadku. Z rozkładu odpowiedzi wynika również, że stosowanie tej metody dydaktycznej oraz innych mniej angażujących form przekazywania wiedzy powodowało wzrost odsetka odpowiedzi o średnim poziomie zapamiętania ćwiczeń. Odpowiedzi uzyskane z ankiety posłużyły do obliczenia wskaźnika $W$ (wzór 1).

$$
W=\frac{-1 a+1 b+2 c+4 d}{n},
$$

gdzie:

$a$ - liczba odpowiedzi „nie pamiętam”,

$b$ - liczba odpowiedzi „pamiętam słabo",

$c$ - liczba odpowiedzi „pamiętam średnio”,

$d$ - liczba odpowiedzi ,pamiętam dobrze”,

$n$ - liczba osób, które udzieliły odpowiedzi na pytanie (bez osób nieobecnych).

Dzięki zastosowaniu wag wskaźnik $W$ umożliwił również uwzględnienie w analizie odpowiedzi innych niż ,pamiętam dobrze”. Wyniki zaprezentowano na rys. 2 . W tym wypadku gry uzyskały najwyższe wartości wskaźnika. Na kolejnych pozycjach znalazły się analiza materiału filmowego i studium przypadku z pierwszych zajęć. Należy jednak podkreślić, że przyjęty tok badania uniemożliwił odfiltrowanie oddziaływania części czynników, które mogły mieć wpływ na poziom zapamiętania przebiegu zajęć. Do najistotniejszych czynników tego typu można zaliczyć różny odstęp czasu od przeprowadzenia poszczególnych ćwiczeń do chwili wykonania badania oraz subiektywność oceny atrakcyjności tematów zajęć. Nie można więc jednoznacznie stwierdzić, która z ujętych w badaniu metod dydaktycznych sprzyja zapamiętaniu przebiegu zajęć, a tym samym lepszemu opanowaniu materiału.

Kolejną kwestią poddaną analizie było to, która z form zajęć, zdaniem studentów, w największym stopniu sprzyja poszerzaniu wiedzy. W ankiecie można było wybrać dwie odpowiedzi spośród sześciu: wprowadzenie teoretyczne, studium przypadku, gra zespołowa, zadania zespołowe, zadania indywidualne i kolokwium ${ }^{4}$. Z wybranych dwóch odpowiedzi należało wskazać tę, którą dana osoba uważa za bardziej istotną (rys. 3). Niestety wiele osób nieprawidłowo udzieliło odpowiedzi na to pytanie, wybierając tylko jedną formę lub nie wskazując spośród wybranych tej istotniejszej. Mimo to widoczna jest przewaga wskazań gier zespołowych oraz zadań zespołowych nad wskazaniami pozostałych form przekazywania wiedzy.

${ }^{4}$ Mimo że kolokwium nie jest formą przekazywania wiedzy, zdecydowano umieścić je wśród możliwych odpowiedzi w celu określenia, jak duży odsetek ankietowanych uzna przygotowywanie się do kolokwium oraz rozwiązywanie zadań w jego trakcie za aktywności poszerzające wiedzę z przedmiotu. Należy podkreślić, iż na zajęciach dwa tygodnie przed terminem kolokwium został określony szczegółowy zakres tematów, a prowadzący udzielał odpowiedzi zarówno na pytania dotyczące organizacji przebiegu kolokwium, jak i obowiązującego materiału. 


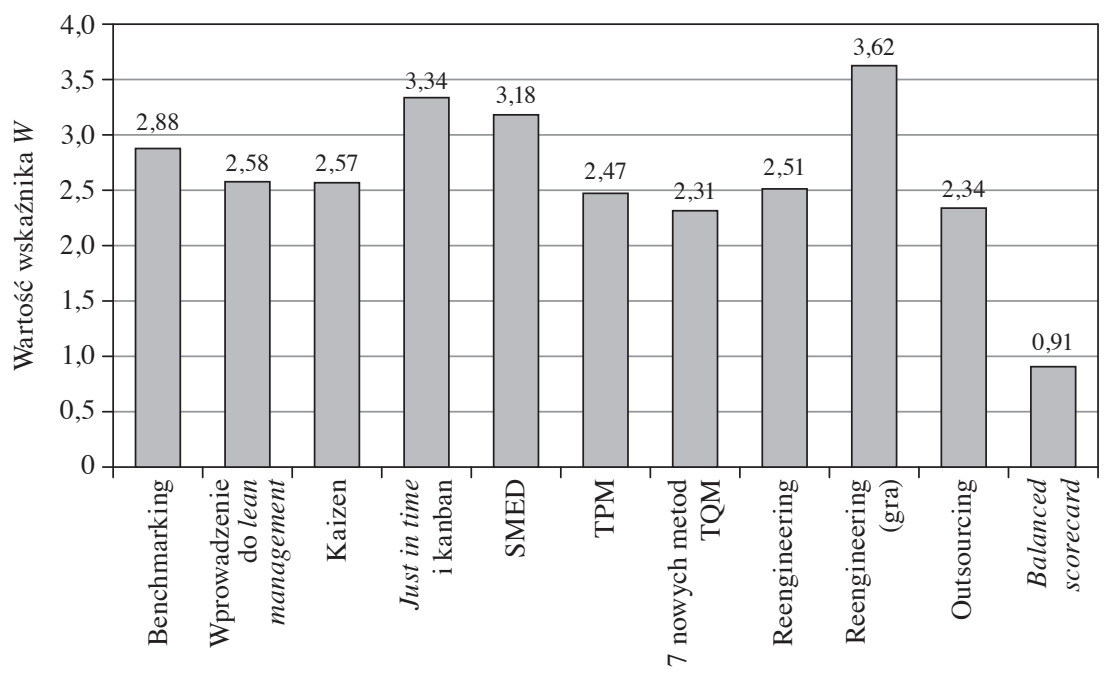

Nazwa ćwiczenia

Rys. 2. Wartości wskaźnika $W$ dotyczące poszczególnych tematów Źródło: opracowanie własne.

Studenci zostali także zapytani o to, które ich zdaniem zajęcia miały najbardziej interesujący przebieg (rys. 4). Najbardziej atrakcyjną dla studentów metodą dydaktyczną okazały się gry. Podobały im się również zajęcia połączone z oglądaniem i analizowaniem materiału filmowego. Pozostałe formy zajęć były wskazywane o wiele rzadziej.

Aby ocenić, na ile studenci pamiętają przebieg zajęć z zastosowaniem gry, poproszono o wskazanie roli, jaką odegrali podczas gry Stocznia (rys. 5). Jedynie cztery osoby nie pamiętały, jaką odgrywały rolę. Stanowi to jedynie $2,8 \%$ wszystkich odpowiedzi. Zdecydowana większość osób, tj. 84,5\% (96,7\% osób obecnych na zajęciach), pomimo upływu kilku tygodni od przeprowadzenia zajęć była w stanie dokładnie wskazać odgrywaną przez siebie rolę.

Należy podkreślić, że możliwa stała się również ocena wiarygodności odpowiedzi. W pierwszym punkcie ankiety 19 osób zaznaczyło, że były nieobecne na zajęciach, na których grano w Stocznię, w pytaniu o rolę fakt nieobecności potwierdziło zaś 18 osób. Z porównania odpowiedzi na te dwa pytania wynika, że z 19 osób, które w pierwszym punkcie ankiety zaznaczyły nieobecność na zajęciach z wykorzystaniem Stoczni, cztery osoby wskazały rolę odgrywaną podczas tego ćwiczenia. 


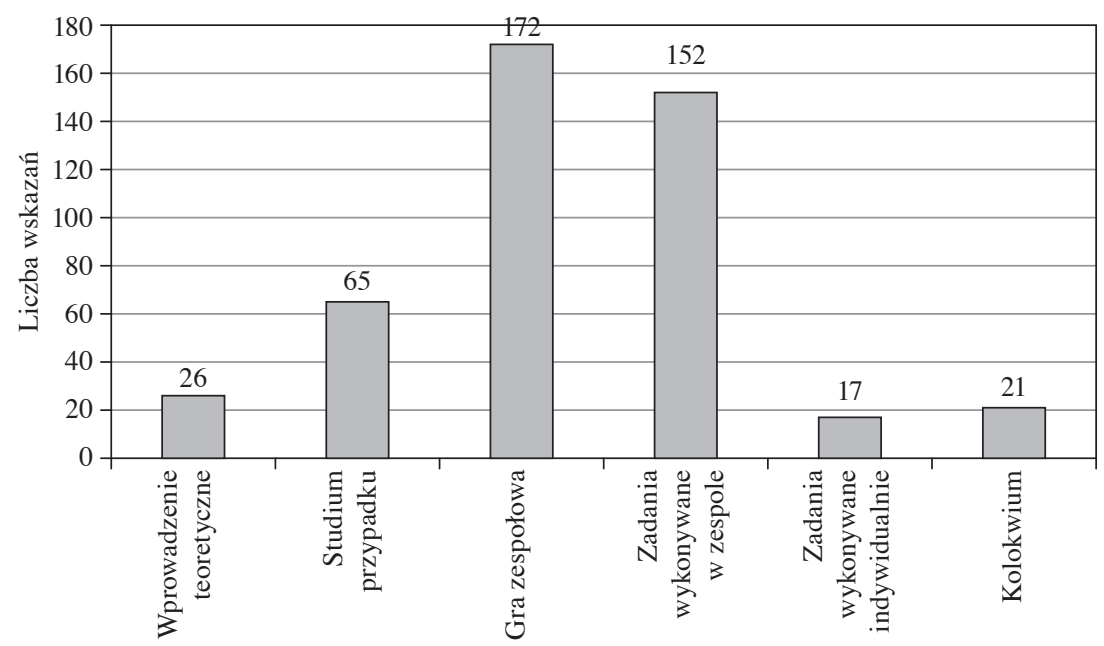

Forma prowadzenia zajęć

Rys. 3. Preferowane przez studentów formy przekazywania wiedzy

Źródło: opracowanie własne.

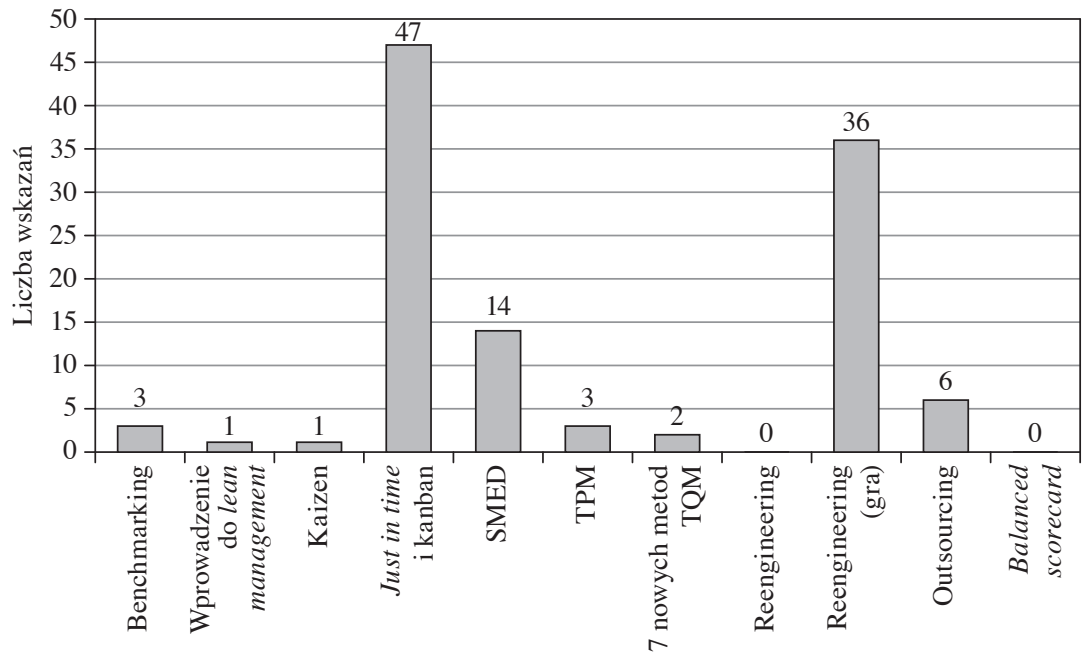

Nazwa ćwiczenia

Rys. 4. Odpowiedzi na pytanie o zajęcia cechujące się najbardziej interesującym przebiegiem

Źródło: opracowanie własne. 


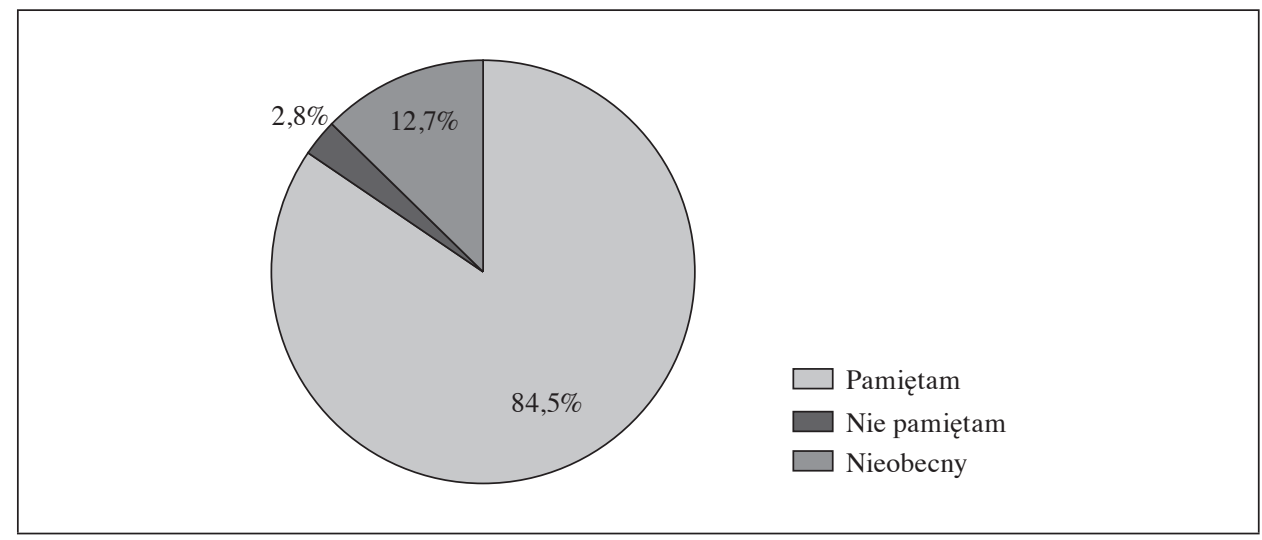

Rys. 5. Odpowiedź na pytanie o rolę odgrywaną w zespole w pierwszej fazie gry Stocznia (wszystkie odpowiedzi wskazujące konkretne role zostały zsumowane i przedstawione na wykresie jako pole obrazujące odsetek studentów pamiętających swoją rolę)

Źródło: opracowanie własne.

Ankietowani zostali również poproszeni o wyrażenie opinii na temat zasadności wprowadzenia współzawodnictwa na zajęciach: mieli odpowiedzieć na pytanie, czy podział na dwa zespoły i wprowadzenie współzawodnictwa podczas ćwiczeń (gry) to dobre rozwiązanie (rys. 6). Prawie wszyscy pytani uznali wprowadzenie współzawodnictwa za dobre rozwiązanie.

Interesujące okazały się odpowiedzi na pytanie, czy zespół, do którego należał dany student, wygrał rywalizację (rys. 7). W zależności od liczby studentów w grupie ćwiczeniowej tworzone są dwa lub trzy zespoły. Wygrać może tylko jeden, statystycznie zatem osób, które brały udział w pracach zwycięskich zespołów, powinno być mniej niż tych należących do zespołów, które przegrały. Z rozkładu uzyskanych odpowiedzi wynika, że część osób odpowiedziała niezgodnie ze stanem rzeczywistym. Szacunkowo odpowiedzi ,przegrał” powinno być co najmniej $10 \%$ więcej.

Na pytanie o to, co należałoby zmienić w ćwiczeniach ze współczesnych koncepcji zarządzania, odpowiedzi udzieliło 70 osób (pominięte zostały puste pola, oznaczenia: ,-, i równoważne). Pytanie to miało charakter otwarty: 19 ankietowanych osób napisało, że nie trzeba niczego zmieniać, 13 osób opowiedziało się za wprowadzeniem większej liczby zajęć aktywizujących całą grupę, w tym gier i zabaw, 11 osób wypowiedziało się na temat studiów przypadków (cztery osoby chciały, aby było mniej tego typu zajęć, trzy - aby było ich więcej, pozostałe postulowały ich modyfikację lub zmianę ich tematyki). Ponadto siedem osób odniosło się do kwestii oceniania, trzy osoby chciały więcej zajęć polega- 
jących na analizie materiału filmowego. 17 osób wypowiedziało się w innych kwestiach, m.in. dopasowania materiału do wiedzy studentów, zwiększenia liczby przykładów praktycznych, organizacji przebiegu zajęć. Na rys. 8 przedstawiono rozkład odpowiedzi na omawiane pytanie.

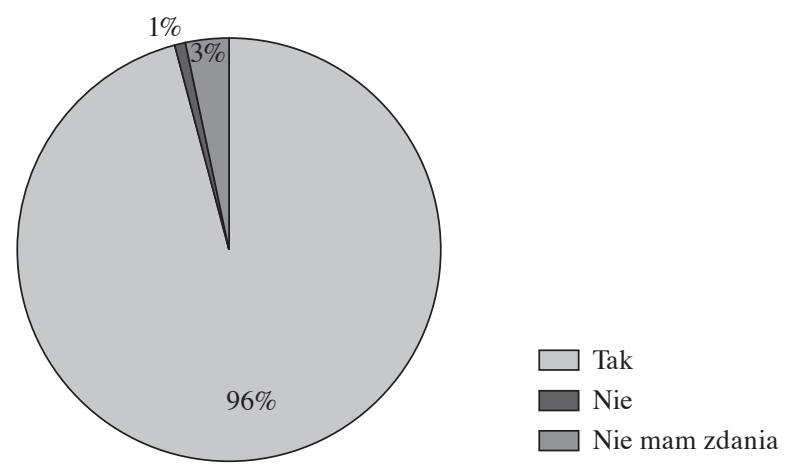

Rys. 6. Odpowiedzi na pytanie, czy podział na dwa zespoły i wprowadzenie współzawodnictwa podczas ćwiczeń (gry) to dobre rozwiązanie Źródło: opracowanie własne.

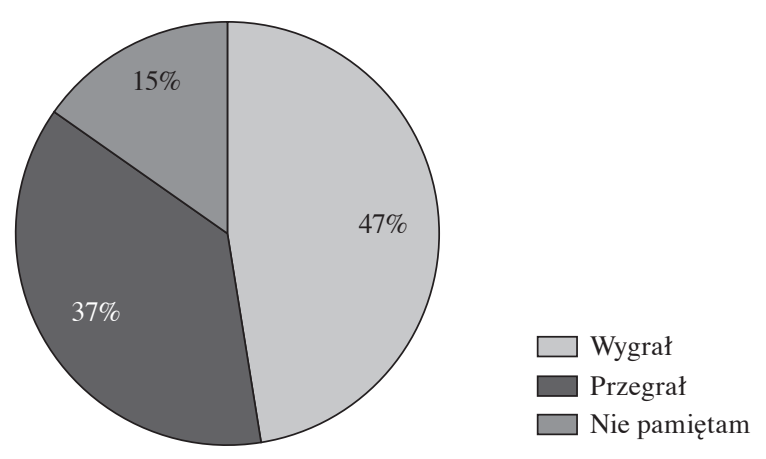

Rys. 7. Odpowiedzi na pytanie, jak zespół, do którego należał student, wypadł w rywalizacji podczas gry Stocznia

Źródło: opracowanie własne. 


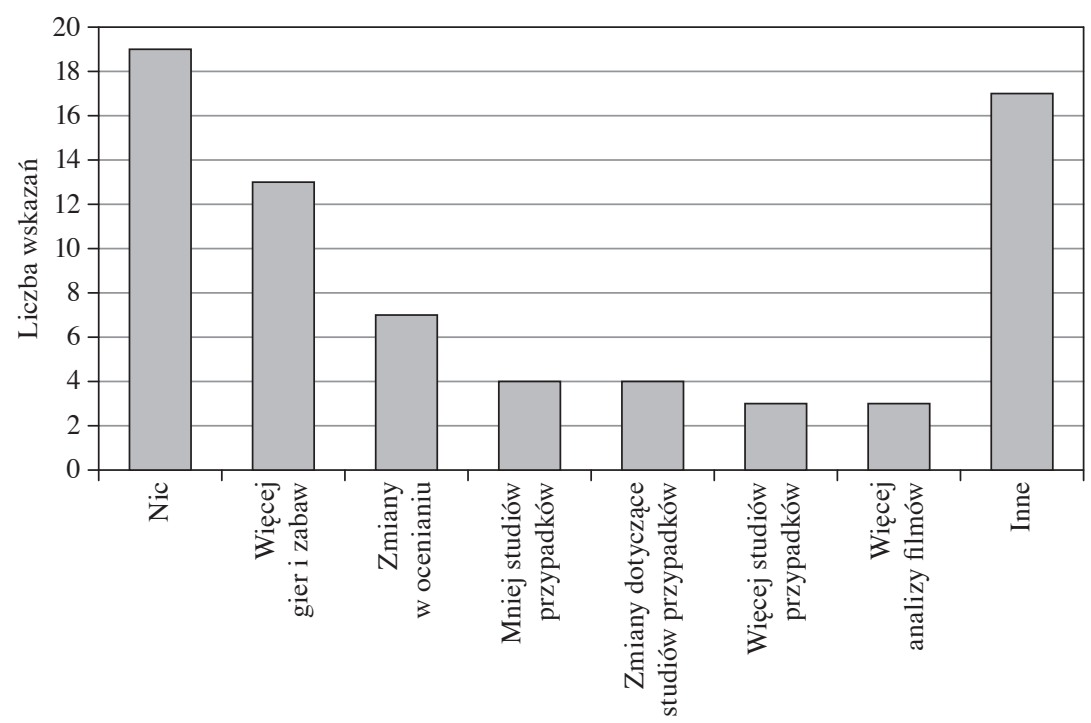

Propozycje zmian

Rys. 8. Odpowiedzi na pytanie o to, co należałoby zmienić w ćwiczeniach ze współczesnych koncepcji zarządzania Źródło: opracowanie własne.

W ostatnim punkcie ankiety studenci mieli możliwość ocenienia zajęć z zastosowaniem akademickiej skali ocen $(2,0-5,5)$. Średnia ocena wyniosła 4,6. Wśród respondentów było $71 \%$ kobiet i $25 \%$ mężczyzn, $4 \%$ badanych nie określiło swojej płci.

\section{Podsumowanie i zalecenia dotyczące wykorzystywania gier symulacyjnych $\mathrm{w}$ procesie nauczania na poziomie akademickim}

Gry to ciekawa, atrakcyjna dla studentów forma prowadzenia zajęć, pozwalająca na zobrazowanie podstaw rozwiązań praktycznych, z którymi nie mieli dotychczas styczności. Przedstawiają one szczególną wartość dydaktyczną, ponieważ rozrywkowy charakter tego typu ćwiczeń sprzyja silnemu zaangażowaniu się uczestników w proces nauczania [Kołodziejczyk i Szołtysek 2012, s. 69]. Gry są ponadto narzędziem służącym do pobudzenia aktywności uczestników ćwiczeń, zwiększenia zaangażowania w ich przebieg, oraz dają możliwość sprawdzenia wiedzy i umiejętności w ramach symulacji [Kołodziejczyk i Szoł- 
tysek 2012, s. 70]. Z punktu widzenia dydaktyka ten ostatni element jest bardzo cenny. Nauczanie metody reengineeringu jest możliwe jedynie wówczas, jeżeli odbywa się w warunkach symulowanych. Jest to zresztą dużo bezpieczniejsze unika się popełniania błędów w wypadku funkcjonowania rzeczywistego przedsiębiorstwa [Mieszaniec i Olejarz-Mieszaniec 2016, s. 61]. Co więcej, tego typu gry ukazują również studentom możliwości wykorzystania symulacji do przetestowania rozwiązania, które już istnieje lub dopiero ma zostać wprowadzone. W ten sposób można poznać jego właściwości, zalety i wady, a takie informacje są podstawą do znajdowania i wprowadzania rzeczywistych usprawnień. Studenci są więc w stanie przekształcić wiedzę teoretyczną w umiejętności praktyczne [Kąkol, Krupa i Krzoska 2012, s. 61].

Istotne jest jednak takie przygotowanie i zrealizowanie przez prowadzącego zajęć z wykorzystaniem gry, aby uzyskać jak najlepsze efekty w zakresie poszerzania wiedzy oraz rozwijania umiejętności i kompetencji społecznych. Jest to przecież cel nadrzędny prowadzenia zajęć na wyższej uczelni.

Prowadząc zajęcia z zastosowaniem gier symulacyjnych, należy przede wszystkim pamiętać o tym, że gra to jedynie narzędzie. Łatwo jest doprowadzić do sytuacji, o której napisała w ankiecie jedna z osób w odpowiedzi na pytanie, co powinno się zmienić w realizacji ćwiczeń: „Zajęcia może i zapadają w pamięć, zadania typu notesy czy statki nie pomagają jednak w zapamiętaniu, o jaką metodę chodziło". Konieczne jest zatem właściwe wprowadzenie teoretyczne, polegające na przedstawieniu koncepcji lub metody będącej tematem zajęć, wskazanie, w którym momencie gry występują kluczowe dla tematu zajęć elementy, oraz podsumowanie gry zawierające odniesienie do poznanej teorii. W wypadku Stoczni prowadzący po pierwszej fazie produkcyjnej powinien nawiązać do kwestii eliminacji marnotrawstwa z procesu jako kluczowej w lean management, a także szczegółowo omówić po zakończeniu gry modelową organizację procesu produkcyjnego wraz z dokładnym rozrysowaniem jej na tablicy. W grze Fabryka Notesów istotne jest z kolei przedstawienie grupie ćwiczeniowej efektów przebudowy procesu oraz odniesienie działań grupy do zasad reengineeringu.

Podczas prowadzenia zajęć z różnymi grupami zaobserwowano pewną prawidłowość: poziom zainteresowania grą wzrasta, jeżeli jest ona poprzedzona ciekawym wprowadzeniem dotyczącym sytuacji przedsiębiorstwa, w którym odbywa się analizowany proces. Takie omówienie kontekstu, mogące nawet zawierać elementy humorystyczne, powoduje, że aktywizują się nawet studenci zazwyczaj mniej zaangażowani w prace zespołów.

Zastosowanie symulacji procesu umożliwia prowadzącemu nawiązywanie w toku późniejszych zajęć, nawet dotyczących innych zagadnień, do sytuacji, które wystąpiły podczas gry. Można więc zobrazować np. problematykę koncentrowania 
się pracowników na usprawnieniach operacji zamiast procesów czy wskazać przykłady marnotrawstwa w procesie.

Zdaniem D. Gruszczyńskiej [2014, s. 238] ważną rolą gry symulacyjnej jest kształtowanie kompetencji społecznych wymaganych na zajmowanych stanowiskach i koniecznych do realizacji obecnych lub przyszłych zadań w sposób odpowiadający przyjętej strategii i istniejącej w organizacji kulturze. Prowadzący nie powinien więc bez wyraźnej potrzeby ingerować w zachowania uczestników będące integralnym elementem przebiegu gry, tym bardziej że w trakcie realizacji zadania wywiązują się dyskusje, zespół musi dojść do konsensusu, a następnie wspólnie odpowiada za osiągnięty rezultat. Należy natomiast odnieść się do tych zachowań już po zakończeniu gry, w jej podsumowaniu.

\section{Literatura}

Auman C. [2011], Using Simulation Games to Increase Student and Instructor Engagement, ,College Teaching”, nr 59, https://doi.org/10.1080/87567555.2011.602134.

Bernaciak A., Brańka T. [2015], Gra jako narzędzie dydaktyczne w kształceniu na poziomie akademickim. „Park Manager Game”, ,Studia Oeconomica Posnaniensia”, vol.3, $\mathrm{nr} 5$.

Gruszczyńska D. [2014], Symulacyjna gra decyzyjna jako narzędzie kształcenia przyszłych specjalistów do spraw logistyki, „Gospodarka Materiałowa i Logistyka”, nr 5.

Harzyńska J. [2012], Metody pracy z uczniami dorostymi, „Edukacja Humanistyczna”, $\mathrm{nr} 1$.

Kąkol U., Krupa M., Krzoska W. [2012], Simulation Game „Factory” as an Innovative Training Tool for Small and Medium Enterprises [w:] Management Consulting for Business and Public Administration, red. M. Ćwiklicki, M. Jabłoński, V. Potočan, Cracow University of Economics Foundation, Kraków.

Kołodziejczyk P., Szołtysek J. [2012], Beer Game - praktyczne refleksje o grze logistycznej $w$ dydaktyce, ,Logistyka”, $\mathrm{nr} 1$.

Mieszaniec J., Olejarz-Mieszaniec E. [2016], Symulacyjna gra decyzyjna jako narzedzie poznawania konsekwencji błędnych decyzji w logistycznym łańcuchu dostaw, „Zeszyty Naukowe Wydziału Elektrotechniki i Automatyki Politechniki Gdańskiej”, $\mathrm{nr} 48$.

Ragin-Skorecka K., Włodarczak Z. [2011], Gry kierownicze, Politechnika Poznańska, Wydział Inżynierii Zarządzania, http://fem.put.poznan.pl/poli-admin/publications/ 3756792FEM\%20gry\%20kierownicze.pdf (data dostępu: 10.08.2016).

Seethamraju R. [2011], Enhancing Student Learning of Enterprise Integration and Business Process Orientation through an ERP Business Simulation Game, „Journal of Information Systems Education", vol. 22, nr 1.

Tao Y.H., Yeh C.R., Hung K.C. [2015], Validating the Learning Cycle Models of Business Simulation Games via Student Perceived Gains in Skills and Knowledge, „Educational Technology \& Society", vol. 18, nr 1. 
Wawrzeńczyk-Kulik M. [2013], Symulacyjna gra decyzyjna jako narzędzie wspomagajq̨e nauczanie w ramach przedmiotu „Podstawy przedsiębiorczości”, „Zeszyty Naukowe Wyższej Szkoły Ekonomii i Innowacji w Lublinie. Seria: Ekonomia”, t. 6, nr 1.

\section{The Use of Simulation Games for Education in Contemporary Management Concepts}

(Abstract)

The article presents the results of research into the effects of simulation games used in a university course on contemporary management concepts. Aside from a review of the literature, the article's key findings come from a survey of 142 full-time students in academic years 2014/2015 and 2015/2016. The basic issues surrounding simulation games for education are briefly described and two games used in the study are presented in the first part of the article. The most important results of the questionnaire, along with an interpretation of them, are presented in the further sections. Recommendations on how to use simulation games in the teaching process at universities conclude the paper.

Keywords: teaching methods, simulation games, teaching effects, modern management methods. 